UDK: $351.862 / .863 ; 341.22$

\title{
THE BASIS OF NATIONAL SECURITY IN INTERNATIONAL LAW
}

\author{
Saša Mijalković \\ Dušan Blagojević \\ Academy of Criminalistic and Police Studies, Belgrade
}

\begin{abstract}
One of the major principles of national security in every modern democratic state is the rule of law. This implies the definition of standards relating to vital state and national values, but also the existence of mechanisms and organisations which take care of security (the establishment, jurisdiction, tasks, powers, responsibility, and control thereof). This includes national law (constitution, laws and bylaws), but also international law (conventions, resolutions, charters, covenants, recommendations, court rulings, decisions of international courts, commissions, and arbitration bodies, etc.). Generally, in democracies, national law is based on international law. In this sense, it is possible to speak about international legal foundations of national security which set the framework for the proclamation, regulation and protection of state and national values and interests. In this context, the paper gives an overview of some major international sources of law pertaining to national security.
\end{abstract}

Keywords: national security, the national security system, international law, national security, sources of law.

\section{Introduction}

When elaborating (international) legal foundations of national security, the first question certainly concerns the origin of this concept, which directly correlates with its standardization, i.e., with the relevant legal regulation.

Formally, the concept of national security developed with the emergence of the first state, i.e. with the socio-economic transition from the original human community in the slaveholding society. Materially, this concept was applied in the earliest territorially organised communities which had primitive (but long-lasting) mechanisms of social regulation and a kind of military-hunting (executive and defence) apparatus. This apparatus protected the members of the original communities, their territory, property, and food resources. The security

\footnotetext{
* Associate Professor, sasa.mijalkovic@kpa.edu.rs

** Technical Associate, dusan.blagojevic@kpa.edu.rs
} 
mechanisms of that time were standardized in keeping with customary law, which was widespread practice until the end of the Middle Ages. Such a concept of national security could be called original, primitive, or rudimentary concept (preWestphalian).

Significant modernisation of the national security concept occurred upon the adoption of the Doctrine on the inviolability of sovereignty dating back to the Augsburg Peace in 1555, which gave the right to a sovereign to decide on the religion in his country (cuius region, eius religion - whose country, his religion). This right was confirmed and revised by the Prague Peace of 1635 and the Peace of Westphalia of 1648. The Peace of Westphalia put an end to the Thirty Years' religious war in Europe between the Catholics and the Protestants. It was an atrocious conflict over religion and supremacy of the Holy (Western) Roman Empire and the Pope as the supreme sovereign who ruled on the basis of the divine right, on the one hand, and the pursuit of German feudal lords and the Check state (helped by England, Denmark, and the Netherlands), on the other, to limit the absolutism of the German emperor. The civil war broke out in Bohemia in 1618 and later spread throughout Europe. It was the last feudal war and the first war involving a sovereign country. After it, the European rulers refused to recognize the secular authority of the Roman Catholic Church, replacing the mediaeval system of papal authority by separate states - in terms of geography and politics. Newly liberated countries were given the same legal rights: the territories under their exclusive control, unlimited control concerning the issues of internal politics and freedom in foreign affairs and in concluding treaties with other states. Secular leaders of Catholic states could ignore the papal call to military counter-reformist policies. The concept of state sovereignty according to which no one is above the state implies political authority which is based on territory and autonomy. Territoriality is the right of exclusive political authority over a particular geographic area (internal sovereignty) and autonomy means that no external factor - such as another state - has authority within the borders of a defined state (external sovereignty). ${ }^{3}$

The creation of the first modern (the so-called Westphalian) state is considered to be the moment when the first modern system of international community was created, as well as the origin of international relations that take place among territorial and sovereign states which are equal entities and members of the international community. At the same time, this is the formal origin of the concept of national security. The focus of this concept is on state values (the prerogatives of the state: the territory, sovereignty, foreign policy interests, and national economy), which are protected against armed attacks from the outside, armed rebellions from within, intelligence subversion by internal and external enemies, and economic constraints. ${ }^{4}$

3 J. S. Jr. Nye, Understanding International Conflicts: An Introduction to Theory and History, New York, 1999, str. 207; C. V. Kegli; J. R. Vitkof, Svetska politika - trend i transformacija, Beograd, 2006, str. 121; K. J. Holsti, States and Statehood, Perspectives on World Politics (eds. R. Little, M. Smith), London-New York, 2006, str. 17-23; A. Heywood, Political Ideas and Concepts - An Introduction, London, 1994, str. 49; S. Mijalković, Nacionalna bezbednost, Beograd, 2011, str. 62.

4 S. Mijalković, Obaveštajno-bezbednosne službe i nacionalna bezbednost, Bezbednost, br. 1/2011, Beograd, str. 74-92. 
Such an agenda of security threats has lead to the development of specialized state sectors of public security. Namely, the growing nationalism, in particular following the signing of the Peace of Westphalia in 1648, brought about the development of standing armies and professional diplomacy. This has induced permanent need for improving mechanisms for the protection of interests in international affairs. At the same time, it called for increased intake of information from abroad, which created the need for establishing organisations and procedures for gathering intelligence. The above-mentioned circumstances led to comprehensive development of diplomacy and intelligence activities, their institutionalisation based on legal regulations and the creation of classic legally-arranged intelligence service, which constituted the summit in the development of the state-run security structures at the time. ${ }^{5}$ Since then, states have increasingly founded their security agencies on legal foundations and provided for their work in legal regulations.

Table 1 - The development of the concept of national security

\begin{tabular}{|c|c|c|c|}
\hline & $\begin{array}{c}\text { Pre-Westphalian } \\
\text { concept of national } \\
\text { security }\end{array}$ & $\begin{array}{l}\text { Westphalian concept } \\
\text { of national security }\end{array}$ & $\begin{array}{c}\text { Post-Westphalian } \\
\text { concept of national } \\
\text { security }\end{array}$ \\
\hline $\begin{array}{l}\text { Vital values and } \\
\text { interests }\end{array}$ & $\begin{array}{l}\text { Territory, } \\
\text { agricultural and food } \\
\text { resources, } \\
\text { property of } \\
\text { community members }\end{array}$ & $\begin{array}{l}\text { Territorial integrity, } \\
\text { sovereignty, } \\
\text { national economy, } \\
\text { peace and freedom, } \\
\text { interests in foreign } \\
\text { affairs }\end{array}$ & $\begin{array}{l}\text { The legal system, } \\
\text { the rule of law, } \\
\text { national energy } \\
\text { resources, } \\
\text { information resources, } \\
\text { quality of life, } \\
\text { environment, } \\
\text { national identity, } \\
\text { national pride, honour } \\
\text { and dignity, } \\
\text { human rights and } \\
\text { freedoms, } \\
\text { international order, } \\
\text { intemational law, etc. }\end{array}$ \\
\hline $\begin{array}{l}\text { Dominant threats to } \\
\text { values and interests }\end{array}$ & $\begin{array}{l}\text { Natural disasters, } \\
\text { diseases, } \\
\text { conflicts with other } \\
\text { social groups }\end{array}$ & $\begin{array}{l}\text { Military threats (war, } \\
\text { armed rebellions), } \\
\text { political crime, } \\
\text { threats to the regime, } \\
\text { economic coercion, } \\
\text { intelligence } \\
\text { subversion, } \\
\text { disruption of foreign } \\
\text { policy interests, etc. }\end{array}$ & $\begin{array}{l}\text { Natural hazards, } \\
\text { technical and } \\
\text { technological hazards, } \\
\text { non-military threats } \\
\text { (organized crime, } \\
\text { terrorism), } \\
\text { contemporary } \\
\text { illnesses, } \\
\text { environmental threats, } \\
\text { poverty, economic } \\
\text { crises, etc. }\end{array}$ \\
\hline $\begin{array}{l}\text { Agents protecting } \\
\text { the values and } \\
\text { interests }\end{array}$ & $\begin{array}{l}\text { Hunting groups, } \\
\text { primitive armies }\end{array}$ & $\begin{array}{l}\text { Armies, } \\
\text { intelligence and } \\
\text { security services, } \\
\text { the judicial system, } \\
\text { diplomatic authorities, } \\
\text { police }\end{array}$ & $\begin{array}{l}\text { State and non-state, } \\
\text { military and civil, } \\
\text { nationlal and } \\
\text { international subjects, } \\
\text { organisations and } \\
\text { mechanisms } \\
\text { specialising in } \\
\text { performing the } \\
\text { security function }\end{array}$ \\
\hline $\begin{array}{l}\text { Legal regulations } \\
\text { pertaining to the } \\
\text { values and their } \\
\text { protection }\end{array}$ & Common law & $\begin{array}{l}\text { National legislation } \\
\text { (constitution, statues), } \\
\text { international law (itr } \\
\text { the later stage of the } \\
\text { development of the } \\
\text { concept) }\end{array}$ & $\begin{array}{l}\text { National law } \\
\text { (constitution, laws and } \\
\text { by-laws), } \\
\text { international law, } \\
\text { decisions of } \\
\text { international courts, } \\
\text { commissions, and } \\
\text { arbitral anthorities }\end{array}$ \\
\hline
\end{tabular}

5 For the first time in history, this occurred during the Bourgeois Revolution in England (16401660). Following the deposition of the English King, Charles I, Lord Chancellor Oliver Cromwell used his own influence to establish the first intelligence service under the auspices of the Parliament in 1647. This year is therefore regarded as the date when the intelligence service was established in the true sense and in the legal sense because it was the first time that the scope of its activities in the area of intelligence and security tasks was legally arranged by the supreme representative body of the state (Савић 1998; Мијалковић, Милошевић, 2011). 
While strengthening its capacities for defence against attacks by other states, the state of Westphalia collapsed inside. What caused that was a large number of built-up internal security problems (crime, nationalism, religious extremism, separatism and irredentism, unemployment, poverty, social pathology, etc.) as well as occurrence of some non-military threats (natural disasters, technical and technological accidents, etc.). This concept, with its security mechanisms, was unsustainable. This gave rise to the third, contemporary or the so-called postWestphalian model of national security.

National security today includes security of the society (regardless of ethnic, ethical, racial and ideological origin or commitment of its members) and security of the state, but also their participation in international and global security. It involves a certain condition of protection of their vital interests and values which is optimized by the function of military and civilian, state and non-state sector of the national security system, with relying on numerous international (non-governmental and inter-governmental) subjects in many aspects of international cooperation in the field of security. Entities at all levels of security - individuals, societies, states, and the international community - participate in the protection of national security. States still have all resources (human, material-technical and organisational) for the protection of all levels of security against most challenges, risks and threats. ${ }^{6}$

Thus post-Westphalian national security implies the state of unhindered implementation, development, enjoyment, and optimal protection of national and state values and interests which is achieved, maintained, and improved through the function of security of citizens, national security system and supranational security mechanisms, the absence of (individual, group, and collective) fear of being endangered, as well as collective sense of serenity, certainty and control over the future events and developments of importance for the life of society and the state. ${ }^{7}$

In addition to traditional national values, modern ones include the survival of the state and nation, the quality of life of the citizens and nations, and social welfare, the constitutional and legal order of the state, public order, economic prosperity, the stability of energy supply and information resources, political stability and national unity, national pride and dignity, i.e. honour and reputation, national identity, healthy environment, and other values. National interests are benefits of importance to society and the state and they are related to the attainment, enjoyment and development of national values.

One of the most important principles of the post-Westphalian model of national security is also lawfulness. This includes standardisation of vital state and national values but also mechanisms and organisations responsible for security (their establishment, jurisdiction, duties, powers, responsibilities, and control). This includes national legislation (constitution, laws and by-laws), but also international law (conventions, resolutions, charters, covenants, recommendations, rulings and decisions of international courts). Generally, national legislation should be based on international law. In this sense, it is possible to speak about international legal basis of national security.

$6 \quad$ S. Mijalković, Nacionalna bezbednost, str. 160.

7 Ibidem, str. 161.

[52] NBP • Žurnal za kriminalistiku i pravo 


\section{An Overview of Major International Sources of Law on National Security}

The legal basis of national security encompasses the system of provisions in international and national law which defines, promotes, regulates and protects the state and national values and interests. These provisions are sacrosanct and apply "equally to all and are equal for all". Thus the legal system and the rule of law are the postulates of national security.

The rule of law is the main prerequisite of the Constitution of the Republic of $S_{\text {Serbia }}{ }^{8}$ and it is based on inalienable human rights. It is achieved by free and direct elections, constitutional guarantees of human and minority rights, division of power, independent judiciary and compliance of the government with the Constitution and law. Serbia has a unique legal system. The Constitution is the supreme legal act and all other laws and legal acts must be in keeping with the Constitution, whereas all by-laws must comply with the laws. The ratified international treaties which are not contrary to the Constitution and the generally accepted rules of international law constitute an integral part of the legal system of the Republic of Serbia. The laws and other general acts passed in Serbia must not be contrary to the ratified international treaties and generally accepted rules of international law; they are published prior to going into effect and generally cannot have a retroactive effect.

As the provisions of international law are undoubtedly of importance for national security, here is a brief overview of international sources of law on national security. Since it is hard to list all of them, we shall briefly present some of the most important regulations.

The United Nations Charter ${ }^{9}$ certainly presents one of the major international legal foundations of national security. The objectives of the United Nations are to: maintain international peace and security, and towards that end take efficient collective measures in order to prevent and remove threats to peace and curb acts of aggression and other violations of peace, as well as to, in keeping with the principles of justice and international law, use peaceful means to settle and resolve international disputes or situations that could lead to breach of peace; to develop friendly relations among nations, based on respect for the principle of equality and self-determination of peoples, and take other appropriate measures aimed at strengthening universal peace; achieve international cooperation by solving international problems of economic, social, cultural or humanitarian nature; promote and encourage respect for the rights and fundamental freedoms of all human beings regardless of their race, sex, language or religion and to become the headquarters for harmonizing the actions taken towards achieving these common objectives (Article 1).

These objectives are achieved by taking into account the principles of: sovereign equality of all members of the organisation; conscientious fulfilment of the commitments undertaken by the Charter; settlement of international disputes in peaceful ways that do not violate international peace, security and justice; refraining

8 The Official Gazette of the RS, No. 83/2006, see Articles 3, 194, and 196.

9 The Official Gazette of the DFY, No. 69/1945.

NBP • Žurnal za kriminalistiku i pravo [53] 
from threat of force or use force against territorial integrity or political independence of the states or from any other means inconsistent with the objectives of the United Nations; commitment of the members to provide assistance to the United Nations in any action it takes in accordance with the Charter and refraining from assistance to the state against which the United Nations take preventive or coercive action; ensuring that the states which are not members of the Organisation act in keeping with these principles to an extent necessary for maintaining international peace and security and prohibition of interference by the United Nations in the matters that essentially fall within the internal jurisdiction of a state (Article 2).

The Charter promotes the following mechanisms for peaceful settlement of conflicts which may endanger international peace and security: negotiation, investigation commissions, mediation, judicial settlements, resorting to regional institutions or treaties or other peaceful means of their own choice (Chapter VI). It also defines the actions in case of threats to the peace, breach of peace and acts of aggression (Chapter VII). In such situations, the Security Council establishes the presence of the above security threats and decides what measures shall be taken in order to maintain or restore peace and security: appealing on the parties concerned to comply with the measures that the Security Council considers necessary or desirable; taking measures which do not entail the use of armed force (complete or partial interruption of economic relations and rail, sea, air, postal, telegraphic, radio and other traffic and communication, as well as the severance of diplomatic relations); the use of armed force, i.e. launching actions by air, naval or land forces of the United Nations member states, including demonstrations, blockade and other operations. This certainly does not impair the inherent right to individual or collective selfdefence of the states in case of an armed attack, until the Security Council takes one of the above actions. The implementation of self-defence measures is to be reported to the Security Council without prejudice to the powers and responsibility of the Security Council to take action in keeping with the Charter in order to maintain or restore international peace and security (Article 51).

The Charter further proclaims international economic and social cooperation (Chapter IX) aimed at creating conditions of stability and well-being which are necessary for peaceful and friendly relations among nations (improving the standard of living, economic and social development; resolving international economic, social, health or related problems, development of international cultural and educational cooperation; overall respect for and appreciation of human rights). Finally, in order to resolve international disputes by peaceful means, the International Court has been established (Chapter XIV). The Charter, in addition to this, defines a number of issues of direct or indirect importance for the security of nations and states.

The Declaration on Principles of International Law concerning Friendly Relations and Cooperation of States in accordance with the Charter of the United Nations ${ }^{10}$ promotes and operationalises the ideas and values from the United Nations Charter, including, primarily the following: maintaining international peace

10 Resolution 2625 (XXV) of the United Nations General Assembly in 1970 (The Declaration on Principles of International Law concerning Friendly Relations and Co-operation among States, United Nations, A/RES/25/2625). 
and security; developing friendly relations, cooperation and tolerance among nations; respect for the rule of law and commitments undertaken upon signing international agreements; prohibition of national appropriation or establishing national sovereignty over the universe and celestial bodies, including the Moon; refraining from intervening into internal affairs of other states; the prohibition of military, political, economic or other coercion which is directed against political independence or territorial integrity of a state; the prohibition of threats and use of force against territorial integrity or political independence of another state; obligation to resolve disputes between states in the spirit of the United Nations Charter; sovereign equality of the states; equality and self-determination of the nation; prohibition of subjecting a nation to foreign rule, domination and exploitation; prohibition of violating national unity and territorial integrity of other states. These ideas have been turned into the following principles: to refrain from the threat to use or use of force against either territorial integrity or political independence of other states or in any other manner inconsistent with the objectives of the United Nations; to resolve international disputes between states by peaceful means; nonintervention in matters which fall within national jurisdictions of the states; duty of states to mutually cooperate; equality and self-determination of nations; sovereign equality of states and conscientious fulfilment of obligations undertaken by the Charter (Preamble of the Charter).

On this occasion we shall elaborate on the principle according to which states are urged to refrain from resorting to threats or use of force in international affairs either against territorial integrity or political independence of other states, or in any other way inconsistent with the objectives of the United Nations (Chapter 1). Acts which constitute gross violations of international law include: war of aggression as a crime against peace; any propaganda in favour of war aggression; threats or use of force in violation of the existing borders of some countries, aimed at resolving international disputes (including territorial disputes and issues relating to state borders), as well as violating international demarcation lines (such as the ceasefire lines established by international agreement); repressive measures which entail the use of force; coercion aimed at depriving people of their right to self-determination, freedom and independence; organising or encouraging the organisation of irregular forces or armed gangs, particularly gangs of mercenaries, with a view to their insertion into the territory of another state; organising or inciting civil wars or terrorist acts in the territory of another state; assistance with, tolerance of and participation in such acts; occupying territories of other states or appropriation thereof as result of threat or use of force. Measures recommended for the prevention of such threats involve negotiations aimed at general and complete disarmament, the adoption of appropriate measures which would reduce international tensions among the states and conscientious fulfilment of obligations (in accordance with the principles and generally accepted rules of international law) related to maintenance of international peace and security.

The Declaration on Principles of International Law concerning Friendly Relations and Cooperation among States in accordance with the United Nations Charter determines and provides detailed guidance concerning the issues of relationship between territorial integrity and national sovereignty with the people's right 
to self-determination to the extent of secession. This right is proclaimed by the United Nations Charter, the International Covenant on Civil and Political Rights, ${ }^{11}$ the final Act of the Conference on Security and Cooperation in Europe, and numerous other documents. Namely, it proclaims the principle of equality and selfdetermination of nations, which have the right to determine their political status, in complete freedom and without foreign interference, and to continue their economic, social and cultural development, and every state is obliged to respect this right. The dominant forms of threat to this right include subjecting the nations to foreign rule, domination or exploitation, as well as denying them fundamental human rights. The establishment of a sovereign and independent state, free association and integration with some independent states or establishing any other political system that the nation has freely chosen, represents the manner in which this nation exercises its right to self-determination. Every state is obliged to refrain from resorting to coercive measures that would deprive nations of their right to self-determination. The above-stated cannot be interpreted as an authorisation or instigation to any actions aimed at destroying or endangering, completely or in part, the territorial integrity, political independence and national unity of any sovereign and independent state which acts in keeping with the principle of equality and self-determination of the nation and which is governed by democratically elected government (Chapter V).

In this regard, the states participating in the Conference on Security and Cooperation in Europe regard all their borders mutually inviolable, as well as the borders of all European states. They have made a commitment to refrain from any act of assault or act of occupation or usurpation of the part or the whole of the territory of any participating states (the principle of inviolability of borders). They also pledged to respect the territorial integrity of other states and to refrain from any action which is inconsistent with the objectives and principles of the United Nations Charter, which is directed against the territorial integrity, political independence or unity of any participating state, and in particular from any such action as may pose a threat of force or use of force. They shall refrain from making the territory of another state the object of military occupation or other measures of direct or indirect use of force contrary to international law, or the object of appropriation by such measures or threat thereof. No such occupation or appropriation shall be recognized as lawful (the principle of territorial integrity of the state). ${ }^{12}$

This right has been repeatedly abused, misinterpreted and used in ill will, which resulted in the violation of territorial integrity and sovereignty of states by armed insurgencies, terrorism, military interventions, and self-proclamation of new states and secession of parts of state territories. International politics that protects the interests of the great powers and the centres of political and economic power often places them "above international law" and above the inviolability of territory and sovereignty of "small", less prosperous states.

Our constitution proclaims the unity and indivisibility of the territory of the Republic of Serbia, as well as the inviolability of borders that can be changed

11 The Official Gazette of SFRY, No. 7/1971

1230 godina OEBS-a: zbirka odabranih dokumenata, Beograd, 2005, str. 28.

[56] NBP • Žurnal za kriminalistiku i pravo 
only in the procedure envisaged for amending the Constitution (Article 8). The inviolability of the state territory is also protected by the Penal Code: ${ }^{13}$ the violation of territorial sovereignty is performed by anyone who penetrates the territory of Serbia in violation of international law (Article 318), and anyone trying to cede or to annex any part of the territory of Serbia by force or in any other unconstitutional manner shall be deemed guilty of endangering territorial unity (Article 307).

The same declaration promotes the principle of sovereign equality of states. According to it, the states have equal rights and duties and they are equal members of the international community regardless of the differences of economic, social, political or any other nature. According to this principle, the states are legally equal; each state enjoys inalienable rights inherent to full sovereignty; each state is obliged to respect the personality of other states; territorial integrity and political independence of the state are inviolable; each state has the right to freely choose and develop its political, social, economic and cultural order, and each state is obliged to fully and conscientiously meet its international obligations and live in peace with other stated (Chapter VI).

The Declaration also promotes the principle of the duty of states not to intervene in matters which fall under the national jurisdictions of other states (Chapter III). No state has the right to intervene, directly or indirectly, for any reason, in internal or foreign affairs of another state. Not only armed intervention, but also any other form of interference or any threat against the personality of a state or its political, economic, and cultural elements, are contrary to international law. Furthermore, no state can implement or support the use of measures of economic, political or any other coercion in order to force another country to participate in the exercise of its sovereign right or to obtain benefits of any kind. All states are also to refrain from organising, assisting, supporting, instigating, or tolerating armed subversions or terrorist activities aimed at using violence to change the regime of another state, as well as to intervene in internal conflicts in another state. The use of force aimed at depriving a nation of its freedom and identity is a violation of their inalienable rights and of the principle of non-intervention. Each state has the right to choose its political, economic, social, and cultural system without interference of any type by any other state. ${ }^{14}$

The Constitution of the Republic of Serbia (Article 2) emphasizes that sovereignty is vested in the citizens who exercise it through referendums, popular initiatives, and through their freely elected representatives; no state authority, political organisation, group or individual may appropriate the sovereignty from the citizens, nor establish a government aside from the freely expressed will of the people.

The Penal Code (Article 305) criminalizes the criminal act of Endangering independence which is committed by anyone who attempts, in an unconstitutional

13 The Official Gazette of the RS, No. 85/2005, 88/2005, correct. 72/2009, 111/2009, 121/2012.

14 Therefore, the absurd constructions about "supervised independence" which used to be suggested to our country as a model for resolving the "Kosmet issue". The status implying "more than autonomy, less than independence" for a part of territory of a sovereign state is a precedent in the history of state and law. This is why it offends/hurt/insults national dignity and threatens national security of a sovereign state.

NBP • Žurnal za kriminalistiku i pravo [57] 
way, to place Serbia into the position of subordination to or dependence on another state. Similarly, a citizen of Serbia who signs capitulation or accepts and recognizes the occupation of Serbia or its part commits the criminal act of Recognizing capitulation or occupation (Article 306).

The Final Act of the Conference on Security and Cooperation in Europe (the so-called Helsinki Final Act) presents the collective views of the Members of the Conference (CSCE) and the guest-countries at the meetings in Helsinki and Geneva in 1973 and in Helsinki in 1975, regarding a number of issues related to security in Europe (Conference on Security and Cooperation in Europe, Final Act, Helsinki, 1975). The most important part of this document is set aside as the Declaration on the Principles which guide the participating member states in their mutual relations. It declares ten principles, including: sovereign equality and respect for the rights inherent in sovereignty; refraining from the threat or use of force; inviolability of borders; territorial integrity of states; peaceful settlement of disputes; non-interference in the internal affairs of other states; respect for human rights and fundamental freedoms, including freedom of thought, conscience, religion, and belief; equality and the right of nations to self-determination; cooperation among states and conscientious fulfilment of obligations under international law. In addition to the Declaration, the Final Act comprises a number of documents, including: The Documents on measures for confidence building and certain forms of security and disarmament, Cooperation in the fields of economy, science and technology and environment (Trade exchange, industrial cooperation and projects of common interest, Provisions pertaining to commercial and industrial cooperation, Environmental issues and cooperation in other areas). ${ }^{15}$

The Charter of Paris for a New Europe adopted at the OSCE Summit in late 1990 proclaimed: a new era of democracy, peace and unity based on mutual respect and cooperation of states; human rights, democracy and the rule of law; economic freedom, social justice and responsibility towards the environment; friendly relations among participating states; security based on reductions in conventional armed forces and strengthening mutual trust; unity of Europe; support for the principles and mission of the UN; guidance for the future regarding the human dimension (human and minority rights and freedoms); security primarily against military threats; development of economic cooperation; environmental protection; culture development; rights of migrant workers; strengthening security and cooperation in the Mediterranean; strengthening the role of non-government organisations, as well as strengthening new institution and processes of the OSCE. ${ }^{16}$

Lisbon Declaration on a Common and Comprehensive Security Model for Europe in the Twenty-First Century, adopted by the OSCE in December 1996 states that freedom, democracy and cooperation among nations - members of the OSCE are the basis of their general security, which will improve by developing a common security space in which states are equal partners. In this sense, it is necessary to jointly face serious challenges which affect security and sovereignty of states, as well as the stability of societies. This primarily includes the lack of respect for human

1530 godina OEBS-a: Opus citatum, str. 25-79.

16 Dokumenti KEBS 1975-1995 (1995), OSCE, Beograd, str 9.

[58] NBP • Žurnal za kriminalistiku i pravo 
rights in all member states of the OSCE, ethnic tensions, aggressive nationalism, violations of the ethnic minorities' rights, serious problems of economic transition, terrorism, organised crime, trafficking in illegal drugs and weapons, uncontrolled migrations and environmental risks. The above-listed security issues need to be addressed jointly, within the OSCE, and in partnership with other international organisations. This approach will be based on cooperative security which rests on democracy, respect for human rights, fundamental freedoms, the rule of law, market economy, and social justice. It rules out any kind of domination and implies trust and peaceful settlement of conflicts. The Declaration further predicts trends and measures in the development of cooperative security. ${ }^{17}$

The Charter for European Security, adopted by the OSCE in late 1999, has taken a common view of the member states regarding security in Europe. Given the size of this document, we shall highlight only some of its aspects, that is, the headings of some parts of the Charter. Firstly, a view was taken regarding the common challenges facing the European countries, emphasizing the drastically changed nature of risks, challenges and threats to security. In place of former interstate conflicts, the European scene is increasingly marked by intra-state conflicts, international terrorism, organised crime, drug trafficking, uncontrolled proliferation of smallcalibre arms and light weapons, economic problems, environmental threats, violations of human - primarily economic and social - rights, etc. Furthermore, the view was taken that the United Nations Charter, the Helsinki Final Act, the Charter of Paris, and many other documents unambiguously form the common ground and foundation for joint actions of the European states to improve overall security. The emphasis here is on the fact that each member state has equal right to security as well as the right to freely choose or change its security arrangements or neutrality, but also the obligation not to strengthen its security at the expense of the security of other states.

Common responses and principles of cooperation with other organisations - the so-called platform for cooperative security - have also been defined. The reason for this is that no country or organisation can successfully respond on its own to contemporary challenges, risks and threats. One of the most important views is that more importance should be given to the human aspect of security, i.e. to human and minority rights, fundamental freedoms and the rule of law. Particularly important views concern the so-called politicalmilitary dimension of the European reality. They focus on control of the socalled military threats to security, disarmament, arms control, confidencebuilding in security, transparency of armed forces, which are all prerequisites for political and military stability, and thereby for comprehensive security on Europe. By analogy, the parameters have also been defined for the economic and environmental dimensions of European security. The gravest threats include environmental risks, depletion of natural resources, and non-integrated economies in transition. The rule of law and combating corruption are the priority tasks of the European countries. The Charter defines common tools for improving dialogues among the OSCE participating states, the principles

17 D. R. Simić, Nauka o bezbednosti - savremeni pristupi bezbednosti, Beograd, 2002, str. 161-164. 
of OSCE field operations, the rules of rapid response to potential and ongoing conflicts, guidelines for improving policing, peacekeeping principles, the establishment of the Court of Conciliation and Arbitration, etc. ${ }^{18}$

The OSCE Strategy to Address Threats to Security and Stability in the Twenty-First Century adopted in late 2003 identified the most serious threats to security in Europe and mechanisms for countering those threats. The most serious threats include conflicts within and between states and their links with terrorism, proliferation of weapons of mass destruction, excessive accumulation and uncontrolled distribution of small and light arms, violations of human rights, mass expulsion, deterioration of social and economic situation and illegal migrations; terrorism; organised crime, especially, the smuggling of migrants, human trafficking, trafficking in illegal drugs, weapons, sensitive materials and technology; discrimination and intolerance, particularly if associated with nationalism, chauvinism, xenophobia, racism, antiSemitism, and violent extremism and ethnicities; economic challenges and threats, which endanger stability and security; environmental risks and threats, primarily involving unsustainable exploitation of natural resources, poor management of waste materials, and pollution; political and military threats, especially the accumulation of conventional weapons, illegal transfer of weapons, distribution of weapons of mass destruction and "new" armed terrorist threats by criminal gangs. The second part of the Strategy contains strategic guidelines for the prevention, suppression, and alleviating the consequences of these challenges, risks and threats to security, through international cooperation among the national security systems and a multi-dimensional approach to common, comprehensive, cooperative and indivisible security. ${ }^{19}$

The OSCE Strategy Document for the Economic and Environmental Dimension (2003) adopted in late December 2003 identified the challenges and threats to economic and environmental sphere of European life and responses to these challenges and threats. Deepening economic and social disparities between and within countries, economic turmoil, financial upheaval, absence of the rule of law, corruption, widespread poverty, and high unemployment rates are some of the factors that contribute to global threats such as terrorism, various forms of extremisms, transnational organised crime, as well as illegal economic activities, including money laundering, illegal trade of all kinds, and illegal migration. Environmental degradation, unsustainable use of natural resources, and inadequate management of waste materials all endanger health, well-being, stability and security of the countries, damage eco-systems, and can cause tensions between countries. A special security-related issue concerns environmental disasters which result from natural causes, economic activities, and terrorist acts. Such phenomena threaten the economic and environmental dimensions of the OSCE's concept of comprehensive security and cooperation. The second part of the Strategy defines responses and measures to be taken. First of all, this includes cooperation measures that would lead to increased development, security and cooperation by integrating national economies into a global economy; by regional integration, access to markets, effective

1830 godina OEBS-a: Opus citatum, str. 93-112.

19 Ibidem, str. 93.

[60] NBP • Žurnal za kriminalistiku i pravo 
financial, energy and industrial businesses; by strengthening conscientious management in the area of public administration and economy, improving transparency and combating corruption; by improving management of public resources, developing favourable business environment and the development of small and medium-sized enterprises; by improving the practice of corporate governance and human resource development; by ensuring sustainable development, environmental protection, and developing mechanisms for international cooperation, etc. ${ }^{20}$

The European Security Strategy adopted in late 2003 by the European Council in Brussels stated that Europe, which had never been more secure, needed to further spread the rule of law and democracy in order to improve its stability ( $A$ Secure Europe in a Better World, European Security Strategy, 2003). This is all the more so since it still faces some traditional security threats such as authoritarian regimes and armed conflicts, occurring in the countries that are not members of the European Union. In this regard, it was emphasized that Europe is ready to take on the responsibility for global security and for building a better world, to which all European countries should contribute. The Strategy pointed out to global challenges and key threats to security. It ruled out the possibility of a largescale aggression in place of which Europe is faced with a number of less visible and therefore less predictable threats, the most dangerous among which include terrorism, proliferation of weapons of mass destruction, regional conflicts, failed states (through poor government, corruption, abuse of power, lack of accountability, and civil conflicts), and organised crime.

The strategic objectives of Europe have been defined so as to incorporate addressing threats, that is, prevention and suppression of security threats, mechanisms of international cooperation, respect for the rule of law, building security in the surrounding by promoting and building stability in the close and broader surrounding in joint efforts with the US, Russia, and NATO; strengthening the international order based on effective multilateralisms, i.e. reinforcing trust and cooperation in the field of security through strengthening the role of international organisations (primarily OUN, EU, CoE, OSCE). Finally, the Strategy defined the political implications for Europe, pointing to the need to develop a strategic culture that supports early, rapid, and powerful intervention for more effective crisis management. In this respect, Europe has to be more active, especially in terms of prevention, more capable (with advanced methodology of solving security problems), more coherent, more synchronised in the area of improving security and cooperation with its partners. This would contribute to a more effective multilateral system that would lead to a fairer, safer and more united world. ${ }^{21}$

Although the entire European Union Treaty of Maastricht from 1992 can be said to present a serious security project, we shall here briefly focus on the provisions concerning common foreign and security policy (The Maastricht Treaty, Final Act and Declarations, 1992). Specifically, the provisions state that the Union and the Member States define and implement common foreign and security policy aimed

2030 godina OEBS-a: Opus citatum, str 149.

21 Bezbedna Evropa u boljem svetlu - Evropska strategija bezbednosti, International and Security Affairs Centre, Beograd, 2006. 
at: protecting common values, basic interests, and independence of the Union: strengthening security of the Union and its Member States in all forms; maintaining peace and strengthening international security in keeping with the United Nations Charter, the Helsinki Final Act, and the objectives of the Charter of Paris; promoting international cooperation; development and strengthening democracy and the rule of law as well as respect for human rights and fundamental freedoms. The Union pursues these objectives by establishing permanent cooperation among the Member States for pursuing policy (exchanging information and making arrangements in the Council on any matter of general interest in the field of foreign policy and security, the harmonization of national policies with the common positions, and jointly advocating the stands of Member States in other international organisation and at international conferences) and the gradual implementation of joint actions through procedures defined by the provisions on the common foreign and security policy. ${ }^{22}$

Similar foundations are derived from the rights of the military-political associations of states. The North Atlantic Treaty Organisation (NATO) founded in April 1949 specified that the Alliance would, in the spirit of the United Nation Charter, peacefully resolve all international disputes that the Member States might get involved in, so as not to threaten international peace, security and justice, at the same time refraining from threat or use of force in any way inconsistent with the objectives of the United Nations (The North Atlantic Treaty, 1949). In addition, the member states undertake to develop peaceful and friendly international relations by strengthening their free institutions, as well as by eliminating conflicts in international economic policy and developing economic cooperation.

To this end, the parties to the treaty pledged to maintain and develop their individual and collective capacities to resist armed attacks, separately and jointly, by continuous and effective self-help and mutual aid. An armed attack against one or more of them shall be considered to be an attack against all members of the Treaty. Consequently, in the spirit of provisions of the United Nations focusing on the right to individual and collective self-defence, assistance will be provided to the party or parties to the Treaty attacked by taking (either individually or jointly) actions that are deemed to be necessary (including the armed forces) with the aim of establishing and maintaining a secure North Atlantic area. The Security Council shall be immediately informed of any attack and countermeasures, which will be terminated when the said body takes necessary measures for the establishment and maintenance of international peace. ${ }^{23}$

The Alliance's New Strategic Concept from November 1991 notes the new strategic environment of the upcoming post-Cold War era, without division between blocs and with significantly reduced threat of a large-scale war (The Alliance's New Strategic Concept, 1991). New challenges and risks to security are associated with unfavourable consequences of instability caused by serious economic, social and political difficulties, including ethnic conflicts and territorial disputes facing many countries of Central and Eastern Europe. The purpose of the Alliance remains the

22 S. Lučić, Razvoj zajedničke spoljne i bezbednosne politike u Evropskoj uniji, Bezbednost, br. 2/2004, Beograd, str. 177-190.

23 Forum za bezbednost i demokratiju, Priručnik za NATO, Beograd, 2005, str. 369.

[62] NBP • Žurnal za kriminalistiku i pravo 
same and it is achieved by preserving the degree of military capability sufficient to prevent war and ensure effective defence; by overall ability to successfully manage crises that affect security of its members; making political efforts to encourage dialogue with other nations and actively finding access to European security through cooperation, which includes the area of arms control. ${ }^{24}$

The new NATO strategic concept - active engagement in modern defence from 2010 confirmed the obligations of NATO members related to mutual defence, including new security threats (Strategic Concept for the Defence and Security of the Members of the North Atlantic Treaty Organisation : Active Engagement, Modern Defence, 2010); it committed the Alliance to preventing and managing crises and stabilising post-conflict situations, primarily through close cooperation with the $\mathrm{UN}$ and the EU; the partners are offered possibility for greater political engagement with NATO; NATO pledged to create conditions for a world without nuclear weapons, but stressed that NATO would remain a nuclear-armed alliance until this type of weapon exists; it emphasized openness to all democratic countries of Europe which can meet the standards of membership, because enlargement contributes to the united Europe, free and at peace; it showed the tendency for NATO to remain a unique community of "freedom, peace, security and shared values". Its aim was to increase effectiveness of the NATO defence against threats of proliferation of nuclear and other mass destruction weapons and terrorism, conflicts outside the Alliance, cyber attacks, threats of using laser weapons, electronic warfare, space technology, etc. Finally, it pointed out to the importance of the environment, natural resources, health risks, water shortage, and increased energy needs, which NATO is to pay special attention to. ${ }^{25}$

The Invitation to Partnership for Peace by the North Atlantic Alliance member states showed their intention to strengthen security and stability in Europe and launched a program to improve dialogue and partnership between NATO and the countries that are not its members (Riga Summit Declaration, 2006). Partnership for Peace programme, which operates under the authority of the NATO Council, establishes new security relationships between the Alliance and its partners for peace by broadening and reinforcing political and military cooperation throughout Europe, enhancing stability, reducing threats to peace and building strengthened relationships, by promoting the spirit of practical cooperation and commitment to democratic principles. NATO will consult with any active member of the Partnership for Peace reporting on an immediate threat to its territorial integrity, political independence or security. To this end, it plans to improve the transparency of the defence budgets and civilian control of defence ministries of all member countries, step up joint military planning, and organise joint military drill, etc. ${ }^{26}$

In addition to the above-mentioned documents, the international foundations of national security certainly appear in numerous other documents but technical reasons do not permit to present all of them in a single paper.

24 D. R. Simić, Opus citatum, str. 210.

25 M. Bajagić, Međunarodna bezbednost, Beograd, 2012, str. 32.

26 LJ. Stajić, Osnovi bezbednosti, Beograd, 2004, str. 368.

NBP • Žurnal za kriminalistiku i pravo [63] 


\section{Conclusion}

This, indeed, presents an excerpt from a number of international documents which, among other things, provide international foundations for certain elements of organisation and functioning of national security. With the development of societies and international community, international law has also developed. As more and more legal subject matter pertains to the area of security, the new area of the co-called international security law will probably differentiate itself, whereas at the national levels there will be the area of national security law. Generally, international security law is progressively conceived. Its "affliction" is that it is often maliciously interpreted and selectively applied or not applied at all. Public law is frequently ousted by the right of the stronger and interpreted tendentiously, due to inappropriate control over international organisations.

This thesis is supported by the fact that a crisis has affected the United Nations, the only universal international organisation of collective security. Although organised in a modern way, offering extremely progressive solutions for protecting peace and security of mankind at the time when it was created, the organisation is much in need of a reform. Changes must start from the very United Nations Charter, which does not completely resolve the issues of armed insurgencies, civil wars, and other internal conflicts. Although, in principle, it promotes the principle of non-interference in the internal affairs of sovereign states, the United Nations have repeatedly intervened into the sovereignty of certain states, failed - through their passive attitude - to prevent NATO from interfering in such situations (Bosnia and Herzegovina, the Federal Republic of Yugoslavia, Afghanistan, Iraq, Libya, etc.) or had no success in the prevention of mass atrocities against civilian population (Rwanda, Congo, Somalia, etc.). Besides the lack of legal arrangements concerning certain issues, the problem in the functioning of international organisations is also their instrumentalisation by the great powers, which are their main financiers. In addition, the great powers dominantly participate in the creation of legislation, its interpretation and implementation according to the principle of "multiple standards", depending on their foreign policy interests. Thus the United Nations' role in maintaining international peace and security is being gradually taken over by NATO.

However, despite everything, there is no doubt as to significance of international law standards in the area of national security. It creates the basis for the security of democratic states to be arranged in a similar way. This greatly contributes to the agenda of shared values and interests of enlightened nations and facilitates international cooperation in the sphere of security.

\section{References}

1. 30 godina OEBS-a: zbirka odabranih dokumenata, Misija OEBS u SCG, Beograd, 2005.

2. A Secure Europe in a Better World, European Security Strategy, 2003. Council of European Union, 2003, dostupno na: http://www.consilium.europa. 
eu/uedocs/cmsUpload/78367.pdf (16.04.2013.) Primedba: datum u zagradi odnosi se na datum pristupa autora određenom sadržaju.

3. Bajagić, M; Međunarodna bezbednost, Kriminalističko-policijska akademija, Beograd, 2012.

4. Bezbedna Evropa u boljem svetlu - Evropska strategija bezbednosti, International and Security Affairs Centre, Beograd, 2006.

5. Charter for European Security,. Organization for Security and Co-operation in Europe, OSCE, 1999, dostupno na: http://www.osce.org/mc/17502(16.04.2013) Primedba: datum u zagradi odnosi se na datum pristupa autora određenom sadržaju

6. Charter of Paris for a new Europe, (15 Years After the Charter of Paris for a New Europe: Problems, Challenges and Risks, Slovenia, 2005). Organization for Security and Co-operation in Europe, OSCE, dostupno na: http://www.osce.org/ mc/39516 (16.04.2013.) Primedba: datum u zagradi odnosi se na datum pristupa autora određenom sadržaju.

7. Conference on security and co-operation in Europe, Final Act, (Annual report, 2007 edition) Organization for Security and Co-operation in Europe, OSCE, dostupno na: http://www.osce.org/mc/39501?download=true (16.04.2013). Primedba: datum u zagradi odnosi se na datum pristupa autora određenom sadržaju.

8. Dokumenti KEBS 1975-1995, OSCE, Beograd, 1995

9. Heywood, A.; Political Ideas and Concepts - An Introduction, MacMilan Press LTD, London, 1994.

10. Holsti, K. J.; States and Statehood, Perspectives on World Politics (eds. Little, R., Smith, M.), Routledge, London-New York, 2006.

11. Kegli, Č. V., Vitkof, J. R; Svetska politika - trend i transformacija, Centar za studije Jugoistočne Evrope, Fakultet političkih nauka i Diplomatska akademija MSP SCG, Beograd, 2006.

12. Lisbon Document,. Organization for Security and Co-operation in Europe, OSCE, 1996, dostupno na: http://www.osce.org/mc/39539?download=true (16.04.2013). Primedba: datum u zagradi odnosi se na datum pristupa autora određenom sadržaju.

13. Lučić, S; Razvoj zajedničke spoljne i bezbednosne politike u Evropskoj uniji, Bezbednost, broj 2/2004, Ministarstvo unutrašnjih poslova Republike Srbije, Beograd.

14. Mijalković, S; Milošević, M; Obavještajno-bezbjednosna djelatnost i službe, Visoka škola unutrašnjih poslova, Banja Luka, 2011.

15. Mijalković, S; Nacionalna bezbednost, Kriminalističko-policijska akademija, Beograd, 2011.

16. Mijalković, S; Obaveštajno-bezbednosne službe i nacionalna bezbednost, Bezbednost, br. 1/2011, Ministarstvo unutrašnjih poslova Republike Srbije, Beograd.

17. Nye J. S. Jr.: Understanding International Conflicts: An Introduction to Theory and History, Longman, New York, 1999. 
18. OSCE Strategy Document for the Economic and Evironmental Dimension. Organization for Security and Co-operation in Europe, OSCE, dostupno na: http://www.osce.org/eea/20705 (16.04.2013). Primedba: datum u zagradi odnosi se na datum pristupa autora određenom sadržaju.

19. OSCE Strategy to Address Threats to Security and Stability in the Twety-first Century, Organization for Security and Co-operation in Europe, OSCE, 2003, dostupno na: http://www.osce.org/mc/17504 (16.04.2013). Primedba: datum u zagradi odnosi se na datum pristupa autora određenom sadržaju.

20. Priručnik za NATO, Forum za bezbednost i demokratiju, Beograd, 2005.

21. Riga Summit, North Atlantic Treaty Organization, 2006, dostupno na: http:// www.nato.int/docu/comm/2006/0611-riga/presskit.pdf (16.04.2013). Primedba: datum u zagradi odnosi se na datum pristupa autora određenom sadržaju.

22. Savić, A; Osnovi državne bezbednosti, OIC, Beograd, 1998.

23. Simić, D. R; Nauka o bezbednosti - savremeni pristupi bezbednosti, Službeni list SRJ i Fakultet političkih nauka, Beograd, 2002.

24. Stajić, LJ; Osnovi bezbednosti, Policijska akademija, Beograd, 2004.

25. Strategic Concept For the Defence and Security of The Members of the North Atlantic Treaty Organisation - Active Engagement, Modern Defence (). North Atlantic Treaty Organization, 2010, dostupno na: http://www.nato.int/lisbon2010/ strategic-concept-2010-eng.pdf(16.04.2013). Primedba: datum u zagradi odnosi se na datum pristupa autora određenom sadržaju.

26. The Alliance's New Strategic Concept, North Atlantic Treaty Organization, 1991, dostupno na: http://www.nato.int/cps/en/natolive/official_texts_23847.htm (16.04.2013). Primedba: datum u zagradi odnosi se na datum pristupa autora određenom sadržaju.

27. The Declaration on Principles of International Law concerning Friendly Relations and Co-operation among States, 24 October 1970. United Nations, dostupno na: http://www.un-documents.net/a25r2625.htm (16.04.2013). Primedba: datum u zagradi odnosi se na datum pristupa autora određenom sadržaju.

28. The Maastricht Treaty, Final Act and Declarations, 1992, Eurotreaties, 2010 dostupno na: http://www.eurotreaties.com/maastrichtfinalact.pdf (16.04.2013). Primedba: datum u zagradi odnosi se na datum pristupa autora određenom sadržaju.

29. The North Atlantic Treaty, 1949., North Atlantic Treaty Organization, 2009, dostupno na: http://www.nato.int/nato_static/assets/pdf/stock_publications /20120822_nato_treaty_en_light_2009.pdf (16.04.2013). Primedba: datum u zagradi odnosi se na datum pristupa autora određenom sadržaju.

30. Ujedinjene nacije i savremeni svet, Savez udruženja za Ujedinjene nacije, Beograd, 1970. 


\title{
MEĐUNARONOPRAVNI OSNOVI NACIONALNE BEZBEDNOSTI
}

\author{
Saša Mijalković \\ Dušan Blagojević \\ Kriminalističko-policijska akademija, Beograd
}

Rezime: U radu je učinjen osvrt na značajnije međunarodne izvore prava nacionalne bezbednosti. Ovo je, svakako, izvod iz nekolicine međunarodnih dokumenata kojima se, između ostalog, daje i međunarodnopravni osnov pojedinih komponenti organizacije i funkcije nacionalne bezbednosti. Nacionalna bezbednost danas obuhvata bezbednost društva (bez obzira na etničko, versko, rasno i ideološko opredeljenje njegovih članova) i bezbednost države, ali i njihovo participiranje u međunarodnoj i globalnoj bezbednosti. Reč je o izvesnom stanju zaštićenosti njihovih vitalnih vrednosti i interesa koje se optimizuje funkcijom vojnog i civilnog, državnog i nedržavnog sektora nacionalnog sistema bezbednosti, uz oslanjanje na vidove međunarodne saradnje u bezbednosti i na brojne međunarodne (nevladine i međuvladine) aktere. U zaštiti nacionalne bezbednosti učestvuju subjekti svih nivoa bezbednosti: pojedinci, društvo, država, međunarodna zajednica. Jedno od bitnijih načela post-Vestfalskog modela nacionalne bezbednosti jeste i zakonitost. To podrazumeva normiranost vitalnih državnih i nacionalnih vrednosti, ali i mehanizama i organizacija koje se staraju o bezbednosti (njihovo osnivanje, nadležnost, poslove, ovlašćenja, odgovornost i kontrolu). Reč je o nacionalnom pravu (ustav, zakoni i podzakonski propisi), ali i o međunarodnom pravu (konvencije, rezolucije, povelje, paktovi, preporuke, presude i odluke međunarodnih sudova). Načelno, nacionalno pravo bi trebalo da bude zasnovano na međunarodnom pravu. U tom smislu, moguće je govoriti i o međunarodnopravnim osnovama nacionalne bezbednosti $S$ razvojem društava i međunarodne zajednice, razvija se i međunarodno pravo. Kako je sve više pravne materije posvećeno oblasti bezbednosti, to će se vremenom verovatno izdiferencirati oblast tzv. međunarodnog prava bezbednosti, a na nacionalnim nivoima $\mathrm{i}$ - oblast prava nacionalne bezbednosti. Međunarodno pravo bezbednosti je generalno progresivno koncipirano. Njegova problem je $u$ tome što se često zlonamerno tumači i selektivno primenjuje, ili se uopšte ne primenjuje. Javno pravo često se zamenjuje pravom jačeg koji ga tendenciozno tumače i kontrolišu međunarodne organizacije. U prilog ovoj tezi ide i činjenica krize Ujedinjenih nacija, jedine univerzalne međunarodne organizacije kolektivne bezbednosti. Iako moderno organizovana, sa izuzetno progresivnim rešenjima zaštite mira i bezbednosti čovečanstva za vreme u kojem je nastala, ovoj organizaciji je preko potrebna reforma Međutim, i pored svega, nesporan je značaj postojanja međunarodnopravnih standarda u oblasti nacionalne bezbednosti. Time se stvara osnov da bezbednost demokratskih država bude uređena na 
sličan način. To u mnogome doprinosi stvaranju agende zajedničkih vrednosti i interesa prosvećenih naroda, te olakšava međunarodnu saradnju u sferi bezbednosti. 